\title{
The Biggest Loser: Education and Skilled Immigration in Australia
}

\author{
Peter E. Robertson ${ }^{1}$
}

\begin{abstract}
Recent studies indicate that skilled immigration is most likely to achieve only small net welfare gains. Nevertheless, the distributional impact of skilled immigration is potentially large, despite the lack of attention paid it. The paper argues that the recent expansion of skilled immigrants may have led to a crowding out of domestic demand for education. Consequently, the expansion of skilled immigration may have contributed to the 'big squeeze' in Australian universities, rather than easing the mismatch problems in the labour market.
\end{abstract}

\section{Introduction}

There has been a dramatic shift in the composition of immigrant flows to Australia over the last two decades. Between 1990 and 1995 Australia halved its intake of permanent migrants from 120,000 per year to around 60,000. From 2000, however, the intake accelerated to an annual inflow of 140,000 immigrants in 2006. Significantly, nearly all of this expansion was due to people entering under the skilled-migrant category, with little change in the family-reunion category (Productivity Commission 2006). This rapid change in migrant selection policies towards skilled visas implies an increase in the average skill level of immigrants. In particular, as shown by Birrell et al (2006), there has been a dramatic increase in the net inflow of 'Professionals', particularly building and engineering professionals and teachers.

What are the benefits of this change in composition of migrants toward skilled visas? The aim of this paper is to provide a brief survey of economic perspectives of the costs and benefits of importing skilled labour, focusing, in particular, on the recent study by the Productivity Commission (2006) and the ensuing debate. I will argue that there has been insufficient attention given to the distributive consequences of immigration and, in particular, to the effects of skilled migration on the domestic education sector.

\footnotetext{
${ }^{1}$ Peter Robertson, School of Economics, Australian School of Business, University of New South Wales. Email p.robertson@unsw.edu.au. The author wishes to express his gratitude for very useful discussions with Steve Dowrick, Martin Richardson, Rod Tyers, William Coleman and other seminar participants at the ANU, and for the comments of two anonymous referees.
} 


\section{Why has Skilled Immigration Increased?}

The expansion of migrant intakes under the skilled-visa class evolved from initial policy reforms in 1999 that aimed to reduce immigration numbers but increase the skilled-visa intake. According to the former Minister of Immigration and Multicultural Affairs, Philip Ruddock, the focus on skilled visas would help ensure that immigration was in the national interest (see Ruddock 1999, 2000). As discussed above, the skill intake increased quite dramatically in subsequent years - returning total immigrant flows to the pre-1991 recession levels. During her term as Minister for Immigration and Multicultural Affairs (October 2003 to January 2007), Amanda Vanstone justified this expansion as a solution to a 'skills shortage' (DIMA 2006). Likewise the Treasury (2007), in its Intergenerational Report, cites skilled migration as a net benefit to Australia as well as a source of offsetting population ageing.

It is easy to be sceptical about these explanations. As argued by Gittens (2006), the notion of a 'skills shortage' is difficult to reconcile with the basic workings of a market. To the extent that there are acknowledged shortages in some professions, such as health, this seems to be due to government policy specifically a failure to maintain spending in high-cost education sectors (Birrell and Rhapson 2006; Norton 2007). Moreover a so-called skills shortage may, in fact, simply be one side of a general skills mismatch which, according to Miller (2007), is prevalent in the Australian labour market. Skilled immigration may have little effect on the shortage if similar skills mismatches exist within the immigrant labour force.

Nor, according to Guest and McDonald (2002), is increased immigration an appropriate response to population ageing. Their numerical simulations suggest that, due mainly to productivity growth, living standards will increase 84 per cent over the next 50 years under the status quo immigration plan. Of this growth, only five per cent is attributed to immigration. ${ }^{2}$ Thus any realistic policy change in immigration is likely to have an effect on living standards which is some fraction of this already small number. Guest and McDonald (2002) therefore conclude that future levels of per-capita consumption are approximately independent of immigration policy. That is, the effects of ageing are long-term effects and over the relevant time horizon they will be dwarfed by productivity growth.

An alternative view of the skilled migrant expansion, expressed recently by Birrell (2003), is that it is a response to lobby groups that favour immigration, particularly real estate, property development and construction sectors. According to Betts and Gilding (2006) these groups did increase their lobbying

\footnotetext{
2 In a counterfactual experiment, in which immigration is set to zero, they find that living standards increase 79 per cent. The difference is 5 percentage points or 6 per cent of the 84 percentage points.
} 
activities during the lull in the late 1990s, and they suggest that the increase in immigration was then a direct response to this lobbying.

As discussed further below, an attractive aspect of the interest-group theory is that it squares with the standard economic model of immigration. As observed by the Reserve Bank of Australia (2007), however, the pattern of immigration in Australia is pro-cyclical. Hence, given the former government's stated focus on skilled immigrants, the recent expansion of skilled-visa entrants might be simply understood as typical expansion in terms of numbers. This does not necessarily contradict Birrell's (2003) interest-group theory but may help in understanding the direction of the changes in total migrant flows over the last decade.

\section{The Effects of Increasing the Skilled Migrant Intake}

Overall, then, the reasons for the expansion of skilled migrants is unclear. Perhaps because of this, in 2006 the government asked the Productivity Commission (PC) to undertake an economic analysis of the consequences of further expanding the skilled-visa intake by 50 per cent over the next 20 years.

Two economic modelling investigations were commissioned under the rubric of this inquiry. The Centre of Policy Studies (CoPS) was contracted by the PC to implement much of the economic modelling for the PC's report (Giesecke and Meagher, 2006). Further, the Department of Immigration and Multicultural Affairs (DIMA) commissioned Econtech (2006) to prepare a submission to the Productivity Commission's report.

The CoPS MONASH model simulations, published in PC (2006), concluded that a 50 per cent increase in the skilled-migrant intake would increase per-capita output by 0.71 per cent after 20 years. Of this increase only 0.27 per cent is attributed to the higher average skill levels of the migrants. Much of remainder comes about largely as a result of higher employment and participation rates of immigrants. ${ }^{4}$

The PC's study has not been without its critics. In particular, the results partly reflect a negative terms-of-trade effect which Clarke (2007) argues is implausible. The issue is whether the world demand curve faced by Australian exporters is significantly downward-sloping. The MONASH model assumes it is and the fall in world prices as a negative effect on GNP per person. As Gieseke (2007) points out, the assumption of a downward-sloping demand curve for

\footnotetext{
3 Betts and Gilding (2006) offer evidence of the pro-growth lobby, among which includes the fact that from January 2001 to October 2006 The Australian ran 18 pro-immigration editorials and only one opposed to immigration.

4 There are also a number of issues that arise with measuring the skills of immigrants. For a discussion of the assumption underlying skill measurement in the PC's report, see Cuxson and Giesecke (2006).
} 
exports is standard in applied policy models and is backed up by econometric evidence. $^{5}$

By contrast, the Econtech (2006) study found a 1.1 per cent increase in consumption per capita after 20 years. Though somewhat larger than the increase in per capita GNP found by the PC (2006), the terms-of-trade effects are very similar, with a slightly larger deterioration being reported by Econtech (2006). Moreover, as pointed out by the Productivity Commission (2006 Appendix J), a large fraction of these differences is caused by differences in the experiment design. In particular, Econtech (2006) assumes no re-emigration flows of the immigrants. Allowing for this would, according to the PC, reduce their estimate to approximately a 0.9 per cent increase in GNP per capita. ${ }^{6}$ Given this correction, one could argue that, in terms of overall modelling, the long-run results of the two studies are remarkably similar.

The medium-run results of the two studies are less similar, however. Econtech (2006) criticised the PC (2006) for its assumptions regarding the extent to which investors respond to changes in the rental rate on capital. If investors adjust quickly, as Econtech (2006) argues, this tends to raise the long-term economic gains to migration significantly, as more capital accumulates over a given finite horizon. Thus if the Econtech (2006) and Productivity Commission results are compared at 10 years, rather than 20, there is a much larger difference.

The problem is, these differences in the time profile of gains from immigration reflect differences in assumptions regarding adjustment cost parameters. Unfortunately there exist no reliable empirical estimates for these parameters. To this uncertainty we must also add uncertainty over urban congestion costs and benefits, related external environmental costs, economies of scale, and possible impacts on the global supply of skilled workers. Again these issues have dynamic impacts of which we have very little empirical knowledge. Recognition of these possibilities only serves to increase the uncertainly of medium-to-long-run impacts.

Finally, it may well be argued that even a gain of $0.7-0.9$ per cent of GNP after 20 years is a fairly small dividend to a 50 per cent expansion of an already large skilled-migrant program. Moreover, both the PC (2006) and Econtech (2006) studies show that the net benefits from skilled immigration are negative for the first five years (Econtech 2006, Chart 5.1). Thus both studies suggest that the

\footnotetext{
5 It should be noted that in addition to average export prices falling the average domestic price index for consumer goods also falls (PC 2006 Figure 8.3). This has a positive effect on real incomes. One criticism of the terms-of-trade result is that it may be overstated if expansions of exports include quality upgrades. For a discussion of this point, see the report by Rod Tyres in PC 2006 Chapter I. 3.

6 Econtech (2006) does not report GNP or GDP results. In terms of consumption per capita, the values reported in PC (2006) Table G.1 imply an increase in consumption per capita which is about 88 per cent as large as GNP per capita. That is a re-migration-adjusted value of approximately 0.8 per cent after 21 years.
} 
overall gains from skilled immigration are very small in the short term and the modest medium-to-long-term results must be regarded as highly uncertain. ${ }^{7}$

\section{Winners and Losers.}

What is surprising about the skilled-immigration debate in Australia is how little attention has been given to the distributional impacts. Despite the small (possible negative) impacts of skilled migration, economic theory indicates that these aggregate effects may disguise large changes in income between different groups.

Borjas (1995) neatly illustrates this point using the 'textbook' Berry and Soligo (1969) model. ${ }^{8}$ According to Borjas (1995), the presence of these immigrants in the United States (approximately 10 per cent of the US labour force) reduces average wages relatively to what they might be otherwise by a number equal to 1.9 per cent of GDP and raises the returns to capital by 2.0 per cent of GDP. Though these are large redistributions, the net gain is the difference between these numbers, which is just 0.1 per cent of GDP. ${ }^{9}$ Thus the presence of immigrants in the United States represents a transfer of 1.9 per cent of GDP from labour to capital.

The real point of Borjas' analysis is not about the United States but is, rather, a general point about the relative magnitudes of the impacts of immigration: the net benefits will always be small relative to the size of the transfers. Irrespective of the overall national gains, immigration clearly brings about large gains to some groups within the economy.

Although the PC (2006) does not focus on distributional impacts, its study contains considerable information on the impacts across industries and occupations. Skilled-immigrant visas mostly consist of professional categories. Thus it is unsurprising that the PC (2006) found that an expansion of the skilled-visa immigration intake would have a substantial dampening effect on the wage growth of Professionals. It finds that salaries of processionals would

\footnotetext{
7 There are several other potential considerations. First, it is worth noting that a strong ethical case can be made for family-based migration. Studies such as Hamilton and Whalley (1984) and Walmsley and Winters (2005) show, however, that the gains to the immigrants, and hence the world welfare gains, from immigration are very large. This essentially ethical argument for immigration does not necessarily apply for skilled immigrants, however, because of the standard 'brain drain' arguments. See also the discussion in Clarke (2006). Second, within particular occupations and at particular times in history there are also likely to be important knowledge spillovers associated with immigration. But this would seem less relevant in the current age of low communication costs. Finally, as noted by Birrell (2006), current flows of skilled migration serve to offset the outflow of skilled labour.

8 This partial-equilibrium model assumed that factors are fixed in supply, are domestically owned and exhibit diminishing returns. It assumed further that there are no domestic distortions, and there is a perfectly elastic supply of immigrants. See also Clarke and $\mathrm{Ng}$ (1993) for a discussion of these issues and an Australian context.

9 In a model with heterogeneous labour, some types of labour may gain and others may lose depending on the degree of substitutability between the different types. See also, for example, Gang and Rivera-Batiz (1994), Borjas (2003) and Ottaviano Peri (2006).
} 
be 10 per cent lower than they would otherwise have been after 20 years and similar figures hold at much finer levels of occupational disaggregation. ${ }^{10}$ The sector which gains the most from the immigration intake is 'Construction' and, in particular, within that broad sector, 'Residential Building', 'Ceramics', 'Plaster', and 'Cement' all experience substantial increases in demand. ${ }^{11}$

Thus the PC (2006) identifies a number of groups which are threatened by increases in skilled immigration and those which may stand to benefit. ${ }^{12}$ The study generally confirms that workers with substitutable skills will lose, while owners of complementary factors, land and capital, will tend to benefit. However, it also shows that the magnitude of these distributional effects on some groups is large relative to the overall gains in GDP per worker.

\section{Education: The Biggest Loser?}

This distributional analysis of the PC, however, ignores the effects of immigration on domestic skill-supply decisions. For example, the PC (2006) finds that a 50 per cent expansion of skilled immigration causes a reduction of 13 per cent in the salaries of Medical Practitioners, relative to the base case. An expectation of this slower growth in salaries should reduce the demand for medical degrees, with negative consequences for the size of the education sector. ${ }^{13}$

In thinking about the issue of investment decisions, it is useful to consider a familiar textbook Ramsey growth model. ${ }^{14}$ In this model, there are two factors: capital and labour. There is also a unique steady state in which the capital-labour ratio is fixed. A one-off increase in the capital stock puts the economy on a transition path that leads back to the steady state. Along this path, consumption is higher than the steady-state level and investment is lower. An analogous argument in a model with human capital and labour suggests that a one-off increase in skilled immigrants would result in transition with higher consumption but lower human capital investment. Hence we have a 'crowding-out' of education through skilled immigration.

10 More detailed occupational results are reported by Giesecke and Meagher (2006) and Cuxson and Giesecke (2006). The former report, for example, that the wages and salaries of Natural and Physical Science Professionals would be 14 per cent lower with the expansion of skilled migration. Likewise, Medical Practitioners are 13 per cent lower, Teachers are 10 per cent lower and Nurses are 8.8 per cent lower. Broadly, the implied fall in the return to postgraduate degrees is 7 per cent.

11 Indeed, its results show that whether immigration is biased towards skilled migrants or just a mix of skill and family visa, it is these same sectors which benefit the most.

12 These results reflect both the assumed composition of the qualifications of immigrants under the points system and also the relatively specialised skills of these groups that leave them with limited alternatives for substituting into other occupations.

13 The possibility of a crowding out of the domestic education sector has been acknowledged by Chapman and Withers (2002) and Corden (2003). Neither study, however, gives it much credence. A rare empirical study is Baker and Wooden (1992). They investigate, but dismiss, the proposition that immigration acts as a deterrent to employer-sponsored training programs for domestic workers in Australia.

14 For example, see Barro and Sala-i-Martin (1995). 
A similar intuition lies behind the theoretical results of Shea and Woodfield (1996), who consider the steady-state effects of skilled migration on skilled and unskilled wages. ${ }^{15}$ The intuition is also similar to the mechanism that underlies recent simulation results presented by Harris and Robertson (2007). They solve the perfect foresight path for education decisions under the scenario of a temporary expansion of the skilled-migrant intake. According to their estimates, a temporary increase of 20,000 immigrants per year over 15 years (which accords roughly with the increase in migrants between 1999-2005 whose stated occupations was 'Professionals') results in an 8 per cent fall in student enrolments in the short run. Though many caveats would apply to this figure, nevertheless it contrasts sharply with the modelling studies discussed above. ${ }^{16}$

These considerations potentially reverse the earlier conclusions about the distributive effects of skilled migration. With a fixed supply of skilled labour, the burden of adjustment falls upon the wages and salaries of skilled workers. Recognising that incoming workers can substitute away from education, however, changes this story. In this case, skilled workers need not experience slower wages and salary growth to accommodate the increased supply of migrants. Rather, the burden of adjustment falls mainly on the education sector.

\section{So what?}

Crowding out of higher education is not necessarily undesirable. Education is expensive and skilled immigration allows us to achieve the same level of skills in the economy at lower costs and the saving of taxes or fees allows an increase in consumption. Nevertheless, it may be bad for the Australian higher education sector. Moreover it represents a potentially unforeseen distributional impact of the current skilled-visa-based immigration policy.

This leads me to two policy-related questions. First, there is the looming question - if skilled immigration crowds out domestic education, what is the optimal balance? Or, to put it more dramatically, why bother subsidising domestic education if we can import skilled labour?

Education policy was a major theme of the 2007 election and is seen as a crucial part of the current government's policy-reform agenda. Education policy in Australia has always recognised the existence of potential external benefits of having good-quality higher education institutions - particularly spillovers from research. If one accepts that there are significant positive externalities,

15 Because, Shea and Woodfield (1996) find, fewer people become educated, this raises the supply of unskilled labour and tends to reduce wages of unskilled workers, not skilled workers. These findings are somewhat similar to a reversal of the 'Brain Drain' literature, such as Bhagwati and Hamada (1974) and McCulloch and Yellen (1977), which finds that outflows of skilled workers induce an increase in demand for education in the source country.

${ }^{16}$ The possibility of crowding out was discussed by the PC during the course of Its investigation, and is mentioned briefly in PC (2006), but is given little importance. 
then it follows that the effects of skilled immigration on higher education may be socially undesirable. Unfortunately, it is not clear that the government ever considered these potential consequences for domestic students and domestic higher education. Certainly they were not part of the policy modelling analyses by DIMA or the PC. Hence there would seem to be room for improvement in the coordination of education and immigration policies.

It is doubtful, however, that planned migration and education can be efficiently coordinated under the current public higher education system. ${ }^{17}$ It is, at best, only partially true that the higher education sector responds to market incentives. Inflexible funding rules will protect institutions from the consequences of changes in the labour market, including skilled-immigration programs. The inflexibility will impose a cost, however, by generating a mismatch between student demands and courses available.

Indeed, Norton (2007) and Birrell, Edwards and Dobson (2007) provide some evidence that this type of mismatch exists in Australian higher education. ${ }^{18}$ These authors blame quantity constraints on the number of subsidised places in undergraduate programs for a graduate shortage in Australia. More generally, Corden (2005) discusses the big squeeze on higher education in Australia. Somewhat ironically this is perhaps what 'should' happen given the increase in skilled immigration.

Thus, in addition to a careful reconsideration of how much skilled immigration is desirable, two courses of action are required. First, coordination problems may be reduced through the types of reforms suggested by Corden (2005) and Norton (2007), who call for some deregulation of the education system. ${ }^{19}$ Specifically the provision of education services needs to be able to respond to changes in the labour market and to government immigration policy shocks. Second, a clearly specified immigration policy that avoids surprises would also be desirable in order to reduce planning costs and uncertainty for higher education institutions and students.

17 By good planning or good luck for the higher education sector, the expansion of offshore immigrants has been accompanied by the creation of onshore immigration, under which foreign students can apply for immigration. This is likely to have sustainably eased the burden of adjustment on universities.

18 Birrell and Rhapson (2006) argue further that the skilled-immigration policy is responsible at least indirectly — by allowing the mismatches in certain sectors to persist.

19 Specifically, Corden (2005) calls for fewer constraints on full-fee-paying domestic students, the removal of limits to fees and the removal of micro management though 'performance indicator'-based tied grant systems. The cap on domestic full-fee-paying students was subsequently removed in the 2007 Budget. Others, such as Karmel (2001), have emphasised the need for student-scholarship rather than institution-based funding. 


\section{References}

Baker, M. and Mark Wooden 1992, 'Immigration and Its impact on the Incidence of Training in Australia', The Australian Economic Review, 2, pp.39-53.

Barro and Sala-i-Martin 1995, Economic Growth, McGraw Hill, Singapore.

Berry, R.A. and R. Soligo 1969, 'Some Welfare Aspects of International Migration', Journal of political Economy, 77, pp.195-221.

Borjas, George J. 1995, 'The Economic benefits from Immigration', The Journal of Economic Perspectives, 9, 2, pp.3-22.

Borjas, George J. 2003, 'The Labor Demand Curve Is Downward Sloping: Reexamining The Impact Of Immigration On The Labor Market', Quarterly Journal Of Economics, 118, 4, pp.1335-74.

Betts, K. and M. Gilding, 'The Growth Lobby and Australia's Immigration Policy', People and Place, 14, 2, pp.40-52.

Bhagwati, J. N. and K. Hamada 1974, 'The Brain Drain, International Integration of Markets for Professionals and Unemployment: A Theoretical Analysis', Journal of Development Economics, 1, 1, pp.19-42.

Birrell, Bob 2003 "Immigration policy and the Australian labour market" Economic Papers, 22 1, 36-45.

Birrell, Bob 2006, 'Skilled Migrants: Gains and Losses', DIMIA Research Report.

Birrell, Bob and Virginia Rhapson 2006, 'Clearing The Myths Away: Higher Education's Place in Meeting Workforce Demands', paper prepared for the Dusseldorp Skills Forum, Glebe NSW, October.

Birrell, Bob, D. Edwards and Ian R. Dobson 2007, 'The Widening Gap between Demand and Supply of University Graduates in Australia', People and Place, 15, 2.

Chapman, Bruce, and Glen Withers 2002, 'Human Capital Accumulation: Education and Immigration', Australian National University, Centre For Economic Policy Research, Working Paper 452.

Clarke, Harry, and Yew Kwang Ng 1993, 'Immigration and Economic Welfare: Resource and Environmental Aspects', The Economic Record, 69, 206, pp.259-73.

Clarke, Harry 2006, 'The Case for Targeting Skilled Immigrants', paper presented to the 35th Annual Conference of Economists, Curtin University of Technology, Perth, Western Australia, 25-27 September.

Clarke, Harry 2007, Comment on James Giesecke, 'The Economic Impact of a General Increase in Skilled Migration', People and Place, 15, 2. 
Corden, W. Max 2003, '40 Million Aussies? The Immigration debate Revisited', Inaugural Richard Snape Lecture, 30 October, Productivity Commission.

Corden, W. Max 2005, 'Australian Universities: Moscow on the Molonglo', Quadrant, 49, 11.

Cuxson, G and J. Giesecke 2006, 'Economic effects of an increase in the skilled migration program', paper presented to the 35th Annual Conference of Economists, Curtin University of Technology, Perth, Western Australia, 25-27 September.

DIMA 2006, 'Skilled Migrants - Engine Room of Australia's Economy', media release by Amanda Vanstone, 21 September.

Econtech 2006, 'The Economic Impacts of Migration: A Comparison of Two Approaches', report prepared for the Department of Immigration and Multicultural Affairs, 5 April.

Giesecke, James, and G. A. Meagher 2006, 'Modelling the Economic Impacts of Migration and population Growth', Centre of Policy Studies, Monash University General Working Paper G-157, May.

Giesecke, James 2006, 'The Economic Impact of a General Increase in Skilled Migration', People and Place, 14, 3.

Giesecke, James 2007, 'Reply to Harry Clarke On The Economic Effects of Skilled Migration', People and Place, 15, 2.

Gittins, Ross 2006, 'Don't fret about labour shortages', Sydney Morning Herald, 25 September.

Guest R. and I. M. McDonald 2002, 'Prospective demographic change and Australia's policy agenda for the 21 st century', paper presented at Towards Opportunity and Prosperity: The 2002 Melbourn e Institute Economic and Social Outlook Conference, April.

Gang, Ira N., and Francisco L. Rivera-Batiz 1994. 'Labor market effects of immigration in the United States and Europe Substitution vs. complementarity', Journal of Population Economics, 7, pp.157-75.

Hamilton, B., and J. Whalley 1984, 'Efficiency and Distributional Implications of Global Restrictions on Labour Mobility: Calculations and Policy Implications', Journal of Development Economics, 14, pp.1-2, 61-75.

Harris, Richard G. and Peter E. Robertson 2007, 'The Dynamic Effects of Skilled Labour Targeting in Immigration Programs', paper presented at The Australian Conference of Economists, University of Tasmania, Hobart.

Karmel, P. 2001, 'Public Policy and Higher Education', Australian Journal of Management, vol 26, Special Issue, pp.123-44. 
McCulloch, Rachel, and Janet L. Yellen 1975, 'Consequences of a Tax on the Brain Drain for Unemployment and Income Inequality in Less Developed Countries', Journal of Development Economics 2, 3, pp.249-64.

Miller, Paul W. 1999, 'Immigration Policy and Immigrant Quality: The Australian Points System', American Economic Review, 89, 2, pp.192-7.

Miller Paul W. 2007, 'Overeducation and Undereducation in Australia', Australian Economic Review, 40, 3, pp.292-9.

Norton, A. 2007, 'Mismatch: Australia's Graduates and the Job Market', Issues Analysis, 84, 23, pp.1-15.

Ottaviano Gianmarco I.P., and Giovanni Peri 2006, 'Rethinking the Effects of Immigration on Wages', NBER Working Paper No. 12497.

Peter, Matthew W., and George Verikios 1996, 'The Effects of Immigration on Residents' Incomes in Australia: Some issues Reconsidered', Australian Economic Review, 114, pp.171-89.

Productivity Commission 2006, Economic Impacts of Migration and Population Growth, Research Report.

Ruddock, P. 1999, 'The Coalition Government's Position on Immigration and Population Policy', People and Place, 7, 4.

Ruddock, P. 2000, 'Australian immigration in a "Dot Com" World', The Australian Economic Review, 33, 3.

Reserve Bank of Australia 2007, Reserve Bank Bulletin, September.

Shea, K. L. and A. E. Woodfield, 'Optimal Immigration, Education and Growth in the Long Run', Journal of International Economics, 40, pp.495-506.

The Treasury 2007, Intergenerational Report, April, at www.treasury.gov.ai/igr.

Walmsley, Terrie L., and L. Alan Winters 2005, 'Relaxing the Restrictions on the Temporary Movement of Natural Persons: A Simulation Analysis', Journal of Economic Integration, 20, 4. 